\section{Alva Beriansyah}

Dosen Universitas Muhammadiyah

Lampung

Email: Berryalvha@yahoo.co.id

\section{Dyah Mutiarin}

Dosen Magister IImu Pemerintahan Universitas Muhammadiyah Yogyakarta Email: dyahmutiarin@umy.ac.id

http://dx.doi.org/10.18196/

igpp.2015.0038

\title{
Analisis Hasil Reses DPRD dalam Penyusunan Dan Penetapan APBD Kabupaten Ogan Komering Ulu Selatan Tahun Anggaran 2014
}

\begin{abstract}
ABSTRACK
The Parliament recess activity is a form of participation from the community in the planning process of development in the area. Perliament of the South OKU regency implement recess 3 times in one year. The process of recess activities began with preparations of parliament to determine the place, time and all material to be delivered during recess implementations. Preparations of recess participants conducted to determine the aspirations to be delivered during recess. The aspiration to be delivered during the recess comes from Musrembangdes, all aspirations has been delivered during the previous recess and unrealized aspirations, also in village meeting. The first thing that discussed to the implementation of the recess is consulting parliament activities before and after recess. The second things are the expressions of aspirations by recess participant. Aspirations articulated by recess participants will be identified together by the recess participants and parliament. The results of this agenda will be used as a report aspirations recess and it will be submitted to the regional government. Articulate of aspirations during the discussions of KUA and PPAS will be prepared at fractions meeting by asking the opinions of each member in factions by the discussions of the general statements of fractions. The general statement form fraction used as a reference for members of parliaments to follow commission and board budget meeting

Key Words: Recess, Parliament, Politics Budget
\end{abstract}

\begin{abstract}
ABSTRAK
Kegiatan reses DPRD merupakan bentuk partisispasi masyarakat dalam proses perencanaan pembangunan di daerah.DPRD Kabupaten OKU Selatan melaksanakan reses 3 kali dalam satu tahun. Proses pelaksanaan kegiatan reses diawali dengan persiapan DPRD untuk menentukan tempat, waktu dan hal-hal yang akan disampaikan saat reses. Persiapan peserta reses dilakukan untuk menentukan aspirasi yang akan disampaikan saat reses. Aspirasi yang akan disampaikan saat reses berasal dari hasil Musrembangdes, aspirasi yang disampaikan saat reses sebelumnya dan belum terrealisasi serta rapat Pemerintahan Desa. Hal pertama yang menjadi pembahasan dalam pelaksanaan kegiatan reses ialah konsultasi kegiatan DPRD sebelum dan sesudah reses. Hal kedua yakni penyampaian aspirasi oleh peserta reses.aspirasi yang disampaikan oleh peserta reses akan diidentifikasi bersama antara peserta reses dan DPRD. Hasil identifikasi aspirasi akan dijadikan laporan kegiatan reses dan akan disampaikan kepada Pemerintah Daerah. Artikulasi aspirasi dalam pembahasan KUA dan PPAS disusun saat rapat fraksi dengan meminta pendapat setiap anggota fraksi dalam pembahasan pandangan umum fraksi.Pandangan umum fraksi dijadikan acuan bagi anggota fraksi dalam mengikuti Rapat Komisi dan Rapat Badan Anggaran.

Kata Kunci: Reses, DPRD, Politik Anggaran
\end{abstract}




\section{PENDAHULUAN}

Disahkanya UU No 22 Tahun 1999 yang telah di revisi menjadi UU No 32 tahun 2004 dan UU No 23 tahun 2014 tentang Pemerintah Daerah, menandai telah terjadi pergeseran pelaksanaan prinsip otonomi daerah di Indonesia. Berdasarkan UU tentang Pemerintah Daerah, prinsip otonomi daerah menggunakan prinsip otonomi seluas-luasnya, nyata dan bertanggung jawab.Prinsip otonomi daerah seluas-luasnya, nyata dan bertanggung jawab memberikan otoritas yang lebih besar kepada Pemerintah Daerah dalam menyelenggarakan pemerintahan dan mengelola keuangan daerah (Usman, 2004: 109).Prinsip otonomi daerah seluas-luasnya, nyata dan bertanggung jawab juga menyediakan ruang kepada masyarakat untuk berpartisispasi dalam peroses pengambilan keputusan yang berkaitan dengan kebijakan startegis (Takeshi, 2006).

Salah satu wujud untuk mencapai tujuan daari prinsip otonomi daerah ialah dengan penguatan Dewan Perwakilan Rakyat Daerah (DPRD) dalam pembuatan kebijakan publik (Syaukani dkk, 2009: 190). Penguatan DPRD dimaksutkan agar DPRD tidak hanya menjalankan fungsi perwakilan, melainkan juga memperjuangkan kepentingan-kepentingan dari rakyat yang diwakilinya (Marijan, 2011: 42).Tujuan utama dilantiknya seseorang menjadi anggota DPRD ialah untuk memperjuangkan aspirasi rakyat di daerahnya. Hal ini terlihat dari sumpah yang diucapkan oleh setiap anggota DPRD ketika akan mengemban amanah sebagai angota DPRDyang berbunyi "bahwa saya akan memperjuangkan aspirasi rakyat yang saya wakili untuk mewujudkan tujuan nasional demi kepentingan bangsa dan Negara Kesatuan Republik Indonesia".

Berdasarkan UU No 27 Tahun 2009 tentang MPR, DPR, DPD, dan DPRD, secara formal aspirasi rakyat didapat oleh anggota DPRD melalui kegiatan reses. Melalui reses, angota DPRD dapat mengetahui secara lebih detail kondisi masyarakat di daerahnya, sehingga pelaksanaan perencanaan pembangunan serta evaluasi 
pembangunan dapat dioptimalkan dan dimanfaatkan oleh seluruh lapisan masyarakat. Selain itu, reses juga dilakukan untuk memaksimalkan kinerja anggota DPRD.

UU No 27 Tahun 2009 tentang MPR, DPR, DPD, dan DPRD, fungsi DPRD Kabupaten/Kota ialah Legislasi, Anggaran dan Pengawasan. Salah satu wewenang dan tugas DPRD Kabuapten/ Kota ialah membahas dan memberikan persetujuan rancangan peraturan daerah mengenai anggaran pendapatan dan belanja daerah. Anggaran daerah merupakan bentuk perencanaan pembangunan daerah memiliki fungsi strategis karena melibatkan pilihan program, kegiatan, dan kebijakan yang akan dilaksanakan oleh Pemerintah Daerah. Proses penyusunan dokumen perencanaan pembangunan harus melibatkan masyarakat, dan harus peka terhadap kebutuhan masyarakat dan keinginan masyarakat (Sopanah, 2015).

UU No 33 Tahun 2004 tentang Perimbangan Keuangan antara Pemerintah Pusat dan Pemerintah Daerah melahirkan paradigma baru dalam pengelolaan keuangan daerah dan anggaran daerah. Tuntutan pengelolaan keuangan daerah yang berorientasi pada kepentingan warga masyarakat daerah, tuntutan bagi orientasi perilaku kerja DPRD untuk memajukan aspirasi rakyat. Proses anggaran menjadi peluang utama bagi tiap anggota DPRD untuk memajukan kepentingan warga daerah pemilihan yang diwakilinya.

Pada tahun 2013 kesepakatan antara Pemerintah Daerah dan DPRD Kabupaten OKU Selatan bahwa APBD Kabupaten OKU Selatan Tahun anggaran 2014 sebesar Rp 904,221,925,794.44. Setelah 10 tahun menjadi kabupaten dan dengan APBD yang cukup besar, namun pembangunan di Kabupaten OKU Selatan tidak terlaksana dengan maksimal. Hal ini dapat dilihat dari:

1. PEMBANGUNAN INFRASTRUKTUR JALAN KABUPATEN.PANJANG JALAN

Kabupaten di Kabupaten OKU Selatan sepanjang 719,58 Km, 
panjang jalan yang jenis permukaanya masih berupa kerikil sepanjang $147,13 \mathrm{Km}$, jenis permukaan tanah tanah sepanjang 135, $90 \mathrm{Km}$, panjang jalan dalam kondisi sedang sepanjang 132,42 Km dan panjang jalan dalam kondisi buruk sepanjang 34,29 Km.(BPS OKU Selatan 2015: 130).

\section{LAYANAN LISTRIK}

Pada tahun 2013, di Kabuapaten OKU Selatan dari 262 desa/ kelurahan yang ada, terdapat 104 desa/kelurahan yang belum mendapatkan layanan listrik, dan terdapat satu kecamatan yang belum mendapatkan layanan listrik yakni Kecamatan Sungai Are. . (BPS OKU Selatan 2015: 130).

\section{PEMBANGUNAN PARIWISATA}

Sebagai daerah yang memiliki potensi wisata dan memiliki motto "WISATA, namun kondisi wisata di Kabupaten OKU Selatan sangat memperihatinkan.Hal ini dapat dilihat dari kondisi akses jalan masuk kawasan Danau Ranau yang mengalami penyempitan dikarenakan banyak ditumbuhi semak belukar yang masuk kebadan jalan sehingga menyebabkan sulitnya kendaraan roda empat untuk melewati kawasan tersebut. (Palembang tribunnews: 2013).

\section{PENDIDIDKAN.}

Dari 19 kecamatan yang ada di Kabupaten OKU Selatan terdapat empat kecamatan yang belum memiliki sekolah menengah atas, yakni Kecamatan Sindang Danau, Kisam Tinggi, Buay Rawan dan Kecamatan Buana Pemaca. (BPS OKU Selatan 2015: 130).

Melihat fungsi, wewenang dan tugas DPRD Kabupaten/Kota dan kondisi pembangunan di Kabupaten OKU Selatan yang telah diuraikan diatas, maka dalam pokok pembahasan penelitian ini ialah bagaimanan DPRD Kabupaten OKU Selatan melaksanakan proses kegiatan reses dan bagaimana DPRD Kabupaten OKU Selatan 
dalam mengartikulasikan aspirasi masyarakat yang didapat melalui kegiatan reses dalam penyusunan dan penetapan APBD Kabupaten OKU Selatan tahun anggaran 2014?

\section{KERANGKA TEORI}

\section{PARTISIPASI MASYARAKAT DALAM PERENCANAAN PEMBANGUNAN}

Conyers dan Hills dalam Tarigan (2012: 5) mendefiniskan perencanaan sebagai suatu proses yang berkesinambungan yang mencakup keputusan-keputusan atau pilihan-pilihan berbagai alternatif pengguna sumber daya untuk mencapai tujuan-tujuan tertentu pada masa yang akan datang

Huntington dan Nelson $(1997,23)$ mendefinisakan partisispasi sebagai kegiatan warga negara yang bertujuan mempengaruhi pengambilan keputusan oleh pemerintah. Karianga (2011:221-222) mendefinisakan partisipasi merupakan proses dimana seluruh pihak dapat membentuk dan terlibat dalam seluruh inisiatif pembangunan, pembangunan yang partisispatif merupakan proses yang melibatkan masyarakat secara aktif dalam seluruh keputusan substansial yang berkenaan dengan kehidupan masyarakat.

Dengan adanya partisispasi masyarakat dalam proses pembangunan diharapkan dapat mewujudkan pemerintah yang transparan dan akuntabel. Takeshi (2006) mengemukakan bahwa pemerintahan yang akuntabel dan transparan dapat dicapai dengan memungkinkan masyarakat untuk berpartisipasi dalam proses pengambilan keputusan tentang isu-isu strategis yang mempengaruhi kehidupan mereka. Sementara itu, Conyers (1994: 154) mengemukakan ada 3 (tiga) alasan mengapa partisipasi masyarakat mempunyai sifat penting dalam perencanaan pembangunan:

a. Partisipasi masyarakat merupakan suatu alat guna memperoleh informasi mengenai kondisi, kebutuhan dan sikap masyarakat setempat yang tanpa kehadirannya program-program 
pembangunan akan gagal.

b. Masyarakat akan lebih mempercayai program pembangunan jika merasa dilibatkan dalam proses persiapan dan perencanaanya, karena mereka akan lebih mengetahui seluk beluk program tersebut dan akan mempunyai rasa memiliki terhadap program tersebut.

c. Merupakan suatu hak demokrasi bila masyarakat dilibatkan dalam pembangunan masyarakat sendiri.

Partisipasi masyarakat dalam perencanaan pembangunan merupakan bentuk keterlibatan rakyat dalam rangka memecahkan masalah yang dihadapi dan bertujuan untuk mencapai kondisi yang sesuai dengan keinginan masyarakat.partisipasi masyarakat dalam perencanaan pembangunan merupakan perencanaan yang dalam tujuannya melibatkan kepentingan rakyat, dan dalam prosesnya melibatkan rakyat (baik secara langsung maupun tidak langsung. Abe (2002:81).

\section{RESES}

Reses DPRD pada dasarnya berkaitan dengan kegiatan memberi peluang bagi masyarakat tanpa perbedaan rasial untuk partisipasi atau keterlibatan, keterbukaan informasi, akuntabilitas bagi masyarakat, terbangunnya suatu konsensus dalam proses pengambilan keputusan di DPRD.Wasistiono (2009: 215)

Efriza (2014: 258) berpendapat bahwa, reses DPRD merupakan hubungan antara anggota DPRD dengan konstituennya dan sebagai bentuk konsultasi di daerah pemilihanya guna untuk untuk menyerap, menghimpun serta menindaklanjuti aspirasi konstituen atau masyarakat.

\section{ARTIKULASI ASPIRASI MASYARAKAT OLEH PERWAKILAN POLITIK}

Alfred de Gracia dalam Efriza (2014:18) mendefiniskan 
perwakilan politik sebagai hubungan diantara dua pihak, yaitu wakil dengan terwakili yang mana wakil memegang kewenangan untuk melakukan berbagai tindakan yang berkenaan dengan kesepakatan yang dibuatnya dengan terwakil.

Marijan (2011:41) mendefinisikan perwakilan politik ialah adanya relasi antara wakil dan terwakili, yang terbalut oleh kepentingankepentingan, baik kepentingan terwakil maupun wakil didalam konteks politik tertentu yang bisa mencakup desain kelembagaan politik maupun budaya politik yang berkembang di dalam masyarakat.

Dari definisi perwakilan diatas dapat disimpulkan perwakilan politik ialah hubungan proses antara wakil dan yang diwakili dalam rangka memperjuangkan kepentingan pihak yang terwakili sesuai dengan kesepakatan yang dibuat dengan wakil.

Agar perencanaan pembangunan sesuai dengan kebutuhan dan aspirasi masyarakat.DPRD sebagai lembaga perwakilan rakyat mempunyai kewajiban menyerap, menghimpun dan menampung aspirasi rakyat.secara formal kegiatan menyerap dan menghimpun aspirasi rakyat dilakukan oleh anggota DPRD pada masa reses sebagai bentuk konsultasi publik. Anggota DPRD sebagai perwakilan rakyat, melakukan artikulasi terhadap aspirasi masyarakat yang berhasil dijaring pada kegiatan reses (Wasistiono, 2009: 212).Menurut Budiarjo dalam Budiarto (2009) Artikulasi merupakan kegiatan yang dilakukan anggota DPRD untuk merumuskan, membuat dan menyampaikan tuntutan-tuntutan dari masyarakat, kelompokkelompok kepentingan dan kelompok penekan untuk disampaikan kepada pemerintah agar menjadi suatu kebijaksanaan.

Dalam mengartikulasikan kepentingan rakyat, anggota DPRD harus memiliki sifat:

a. Berpihak kepada kepentingan/kebutuhan rakyat

b. Menjaga dan mempublikasikan laporan kegiatan anggota dimana aspirasi dicatat sehingga anggota DPRD dapat bertanggung jawab 
kepada masyarakat yang diwakili.

c. Menegosiasikan dan memperjuangkan aspirasi masyarakat malalui berbagai forum dalam persidangan di DPRD. (Wasistiono, 2009: 189)

\section{POLITIK ANGGARAN}

Mardiasmo (2009:61) mendefinisikan anggaran sebagai pernyataan mengenai estimasi kinerja yang hendak dicapai selama periode waktu tertentu yang dinyatakan dalam ukuran finansial, sedangkan penganggaran adalah proses atau metode untuk mempersiapkan suatu anggaran.

Anthony dan Vijay, (2006:73) mendefinisikan bahwa anggaran merupakan alat penting untuk perencanaan untuk pengendalian jangka pendek yang efektif dalam organisasi.Suatu anggaran beroperasi biasanya meliputi waktu satu tahun dan menyatakan pendapatan dan beban yang direncanakan untuk tahun tersebut. Definisi lain dari anggaran ialah,

Wildavsky, (2009: 111) menyatakan bahwa "Semua anggaran adalah tentang politik; sebagian politik adalah tentang penganggaran: dan penganggaran oleh karena itu harus dipahami sebagai sebagian dari permainan politik. (All budgeting is about politics; most politics is about budgeting: and budgeting must therefore be understood as part of political game). Dari pernyataan diatas dapat dipahami bahwa penganggaran merupakan aktifitas politik, dengan demikian, proses maupun produknya adalah produk politik.

Anggaran publik memiliki beberapa karakteristik khusus (lima hal utama untuk melihat politik dalam anggaran) yaitu : reformisme, tawar-menawar, kepentingan kelompok, proses, dan pembuatan kebijakan) di mana anggaran merupakan proses politik, politik adalah kata dengan sejumlah makna, bahkan ketika itu dipersempit dengan konteks pembuatan keputusan anggaran. (Rubin ,2006:2829) 
Dari perspektif politik, anggaran merupakan

a. Anggaran mencerminkan "pilihan tentang apa yang pemerintah akan dan tidak melakukan"

b. Anggaran mencerminkan prioritas pemerintah sebagai "proses anggaran menengahi antara kelompok dan individu yang menginginkan hal yang berbeda dari pemerintah"

c. Anggaran mencerminkan "proporsi relatif dari keputusan yang dibuat untuk tujuan daerah dan konstituen, dan untuk efisiensi, efektifitas serta tujuan publik yang lebih luas"

d. Anggaran merupakan "alat yang ampuh sebagai akuntabilitas kepada warga yang ingin mengetahui bagaimana pemerintah menggunakan dana masyarakat dan jika pemerintah secara umum mengikuti pilihan masyarakat

e. Anggaran mencerminkan "pilihan masyarakat untuk berbagai bentuk pajak dan berbagai tingkat perpajakan, serta kemampuan kelompok wajib pajak tertentu untuk mengalihkan beban pajak kepada orang lain"

f. Anggaran mempengaruhi ekonomi dan berpengaruh terhadap lapangan kerja

g. Anggaran mencerminkan "kekuatan relatif berbagai individu dan organisasi untuk mempengaruhi hasil anggaran (Rubin 2006: 1) Tarik menarik kepentingan dalam penyusunan anggaran berlangsung sepanjang proses penyusunannya, baik semenjak perancangan dilingkungan eksekutif maupun saat rancangan dibahas dan ditetapkan dilembaga legislatif. Oleh karena itu, walaupun keteribatan aktor lain selalu terjadi, secara politik aktor kunci pada proses penganggaran adalah pejabat publik yang terpilih dalam pemilu dengan birokrasi. Aktor-aktor tersebut akan berusaha memperjuangkan kepentingan politik masing-masing. Norton dalam WaidI, (2008: 117) untuk memahami tentang politik anggaran diperlukan pemahaman tentang: 
a. Struktur formal peran dan tanggung jawab dalam proses penganggaran

b. Peran pemerintah dalam pengambilan keputusan, pilihan politik dan akuntabilitas pada sistem manajemen pengeluaran publik.

c. Jaringan kekuasaan dan pengaruh stakeholder (diluar proses formal) yang mempengaruhi hasil dari proes anggaran.

d. Insentif yang diberikan baik tersembunyi maupun terangterangan atas tinakan yang mempengaruhi politisi dan birokrasi dalam pengambilan keputusan selama penyusunan dan penetapan anggaran.

e. Ruang pengambilan keputusan birokrasi pada semua level proses penetapan anggaran.

\begin{tabular}{|c|c|}
\hline $\begin{array}{l}\quad \text { Proses Kegiaatan Reses } \\
\text { 1. Persiapan kegiatan reses } \\
\text { 2. Keaktifan dalam kegiatan reses } \\
\text { 3. Konsultasi dalam kegiatan reses } \\
\text { 4. Identifikasi masalah-masalah dalam } \\
\text { kegiatan reses }\end{array}$ & $\begin{array}{l}\text { APBD } \\
\text { 1. Tindak lanjut hasil reses dalam } \\
\text { rancangan KUA-PPAS } \\
\text { 2. Artikulasi hasil reses dalam } \\
\text { pembahasan KUA-PPAS } \\
\text { 3. Pengarahan hasil reses dalam } \\
\text { pembahasan KUA-PPAS }\end{array}$ \\
\hline
\end{tabular}

\section{METODE PENELITIAN}

Jenis penelitian yang digunakan dalam penelitian ini ialah metode deskriftif kualitatif. Penelitian kualitatif merupakan penelitian yang bermaksud untuk memahami fenomena tentang apa yang dialami oleh subjek penelitian secara holistik dan dengan cara deskripsi dalam bentuk kata-kata dan bahasa, pada suatu konteks khusus yang alamiah dan dengan memanfaatkan berbagai metode alamiah (Moleong, 2014: 6). Penelitian ini dilaksanakan pada DPRD Kabupaten OKU Selatan Periode 2009-2014 dan masyarakat yang mengikuti kegiatan reses yang dilaksanakan oleh DPRD OKU Selatan pada tahun 2013.

Teknik pengumpulan data pada penelitian ini menggunakan 
teknik dokumentasi dan wawancara. Teknik analisis data dalam penelitian ini menggunakan analisis data model interaktif (interactive model). Miles dkk dalam Sugiyono (2014, 91), Analisis data model interaktif merupakan aktivitas dalam analisis data kualitatif yang dilakukan secara terus menerus sampai tuntas, sehingga data sudah jenuh.

\section{PEMBAHASAN}

\section{PROSES PELAKSANAAN KEGIATAN RESES}

\section{A. PERSIAPAN KEGIATAN RESES}

Persiapan kegiatan reses dimulai dengan rapat Pimpinan DPRD untuk membahas jadwal pelaksanaan kegiatan reses. Rapat Pimpinan DPRD diikuti oleh Ketua DPRD, Wakil Ketua DPRD I, Wakil Ketua DPRD II, seluruh Ketua Fraksi dan Ketua Daerah Pemilihan bersamaan dengan Sekretaris DPRD. Hal yang menjadi pertimbangan dalam menetukan jadwal kegiatan reses ialah jadwal kegiatan DPRD, kegiatan Pemerintah Daerah dan kegiatan peserta reses yang mengikuti kegiatan reses.

Pada tahun 2013 berdasarkan hasil rapat Pimpinan disepakati kegiatan reses I(pertama) pada tanggal 2 Januari sampai dengan 5 Januari, reses II(kedua) dilaksanakan pada tanggal 6 Juni sampai dengan 9 Juni dan reses III(ketiga) dilaksankan pada tanggal 17 Oktober sampai dengan 20 Oktober. (Laporan Reses DPRD OKU Selatan Tahun 2013).

Setelah disepakati jadwal kegiatan reses, jadwal kunjungan ke daerah pemilihan di tentukan berdasarkan rapat Dapil. Rapat Dapil merupakan rapat sesama Anggota DPRD berdasarkan daerah pemilihan yang sama. Rapat Dapil membahas tentang jadwal kunjungan ke kecamatan-kecamatan yang ada di daerah pemilihan, disesuaikan dengan jadwal yang telah disepakati dalam rapat Pimpinan DPRD. Selain membahas tentang jadwal kegiatan kunjungan ke Dapil rapat Dapil juga membahas tentang persiapan 
bahan-bahan yang akan disampaikan pada saat reses dan pendokumentasian kegiatan reses.

Agar peserta reses dapat menghadiri kegiatan reses, dalam menenukan jadwal kunjungan ke Dapil harus sesuai dengan kegiatan masyarakat di Dapil tersebut. Hal yang menjadi pertimbangan dalam menentukan jadwal kegiatan reses ialah kegiatan masyarakat dan jarak antara kecamatan yang satu dengan yang lain.

Kesepakatan jadwal, tempat dan waktu kegiatan reses yang telah disepakati dalam rapat Pimpinan DPRD dan rapat Dapil, di beritahukan oleh Sekretariat DPRD kepada seluruh kecamatan yang ada di Kabupaten OKU Selatan.Undangan kegiatan reses diberitahukan kepada seluruh peserta reses satu minggu sebelum dilaksanakan kegiatan reses. Hal ini dikarenakan agar peserta reses mempersiapkan hal-hal yang akan disampaikan pada saat mengikuti kegiatan reses. Peserta reses yang diundang dalam mengikuti kegiatan reses ialah Kepala Desa serta Perangkanya, Ketua BPD serta Anggotanya, Tokoh Agama, Tokoh Adat, Tokoh Masyarakat, Kepala UPTD, Kepala Sekolah, Karang Taruna dan Ibu-ibu PKK. Kegiatan reses dilaksanakan secara terbuka bagi seluruh masyarakat bila ingin mengikuti kegaitan reses.

Terdapat 3 cara yang dilakukan oleh peserta reses dalam mempersiapkan aspirasi yang disampaikan oleh pesesrta reses:pertama, aspirasi yang sama dengan hasil dari Musrembangdes. Aspirasi yang disampaikan oleh pesesrta reses hampir keseluruhan merupakan hasil dari Musrembangdes. Rencana pembangunan desa yang dihasilkan dari Musrembangdes disampaikan kembali oleh Kepala Desa kepada DPRD pada saat reses.Penyampaian hasil Musrembangdes disampaiakan kembali pada saat reses dimaksudkan agar rencana pembangunan yang telah disepakati saat Musrembangdes dapat terrealisasi.DPRD dapat membantu memperjuangkan hasil Musrembangdes dan hasil Musrembangdes merupakan rencana pembangunan desa yang sesuai dengan 
kebutuhan masyarakat.

Kedua, aspirasi yang akan disampaiakan peserta reses dalam kegiatan reses berasal dari bahan-bahan usulan reses sebelumnya yang belum terealisasi. Aspirasi yang disampaikan saat kegitan reses sebelumnya apabila ada yang belum terealisasi akan kembali diusulkan pada saat reses. Dengan menyampaikan aspirasi yang disampaikan saat reses sebelumnya harapan peserta reses agar aspirasi tersebut dapat segera terrealisasi.

Ketiga, rapat Pemerintahan Desa.Rapat dilaksanakan antara pemerintah desa dengan BPD selaku perwakilan masyarakat desa. Rapat Pemerintahan Desa dilakukan setelah adanya pemberitahuan dari pihak kecamatan bahwa akan diadakan reses. Dengan adanya rapat Pemerintahan Desa sebelum mengikuti reses harapan peserta reses agar aspirasi yang disampaikan saat reses memang benar-benar merupakan kebutuhan masyarakat.

\section{B. KEAKTIFAN PESERTA RESES}

Pada kegiatan reses pertama, jumlah peserta yang mengikuti kegiatan reses sebanyak 1237 peserta. Pada reses kedua, jumlah peserta yang mengikuti kegiatan reses menurun menjadi 884 peserta.Pada kegiatan reses ketiga jumlah peserta yang mengikuti kegiatan reses sebanyak 1080 peserta.Pada reses ketiga jumlah peserta reses meningkat bila dibandingkan dengan jumlah peserta pada reses kedua, namun masih lebih tinggi bila dibandingkan dengan jumlah peserta reses pertama.

Faktor yang menyebabkan tingginya kehadiran peserta reses pertama yakni, kuatnya keingintahuan peserta reses mengenai rencana kegiatan DPRD di tahun ini dan keingintahuan mengenai realisai aspirasi peserta reses pada saat reses ditahun sebelumnya.Pada kegiatan reses kedua, faktor yang menyebabkan menurunnya kehadiran peserta reses yakni, karena reses dilaksanakan pertengahan tahun sehingga peserta reses menganggap aspirasi yang peserta reses 
sampaikan sulit terrealisasi.Pada kegiatan reses ketiga, kehadiran peserta reses meningkat bila dibandingkan dengan kegiatan reses kedua. Faktor yang menyebabkan meningkatnya jumlah peserta reses ketiga bila dibandingkan dengan kegiatan reses kedua ialah, reses ketiga dilaksanakan pada akhir tahun dimana DPRD akan membahas APBD bersama dengan Pemerintah Daerah. Peserta reses menganggap aspirasi yang mereka sampaikan akan dapat terrealisasi.

Pelaksanaan Kegiatan Reses

a. Konsultasi dalam kegiatan reses

Hal pertama yang menjadi pembahasan dalam pelaksanaan kegiatan reses yakni tentang kegiatan yang dilakukan oleh DPRD sebelum dilakasanakannya reses.Selain kegitan yang dilakukan oleh DPRD sebelum reses, DPRD juga menyampaikan rencana kegiatan DPRD setelah diadakanya kegiatan reses. Konsultasi dalam kegiatan reses dimaksudkan agar peserta reses mengetahui kegiatan yang telah dilakukan oleh DPRD dan yang akan dilakukan oleh DPRD setelah reses. Penyampaian kegiatan yang akan dilakukan oleh DPRD setelah reses, diharapakn peserta reses dapat memberikan saran dan usulan kepada anggota DPRD, sehingga anggota DPRD benar-benar mengetahui hal-hal yang menjadi kebutuhan konstituenya dalam melaksanakan kegiatan setelah reses.

b. Identifikasi Aspirasi

Menyerap aspirasi rakyat merupakan tujuan utama dari kegiatan reses yang dilakukan oleh DPRD.Agar dapat mengetahui aspirasi rakyat, setiap peserta reses diberikan kesempatan untuk menyampaikan aspirasinya. Setiap aspirasi yang disampaikan oleh peserta akan di identifikasi bersama-sama antara Anggota DPRD dengan peserta reses. Dengan adanya identifikasi ini diharapkan aspirasi rakyat benar-benar merupakan kebutuhan masyarakat dan sesuai dengan kewenangan dari Pemerintahan Kabupaten.

Berdasarkan laporan reses I, II dan III DPR Kabupaten OKU Selatan tahun 2013 terdapat 242 hasil identifikasi aspirasi. Hasil 
kegiatan reses yang dilakukan oleh DPRD, Dapil II merupakan Dapil yang menyerap aspirasi terbanyak, dengan aspirasi sebanyak 99 aspirasi.Dapil I merupakan Dapil yang paling sedikit menyerap aspirasi, dengan aspirasi sebanyak 66 aspirasi.

\section{TABEL 1 JUMLAH ASPIRASI HASIL IDENTIFIKASI ASPIRASI KEGIATAN RESES I,II DAN III}

\begin{tabular}{ll}
\hline Dapil & Aspirasi \\
\hline Dapil I & 66 \\
Dapil & 99 \\
II & \\
Dapil & 77 \\
III & \\
Jumlah & 242 \\
\hline
\end{tabular}

Sumber: Laporan Reses I, II dan III DPRD Kabupaten OKU Selatan Tahun 2013

Berdasarkan penjelasan proses kegiatan reses diatas, proses kegitan reses yang dilakukan oleh DPRD Kabupaten OKU Selatan dapat digambarkan seperti gambar dibawah ini:

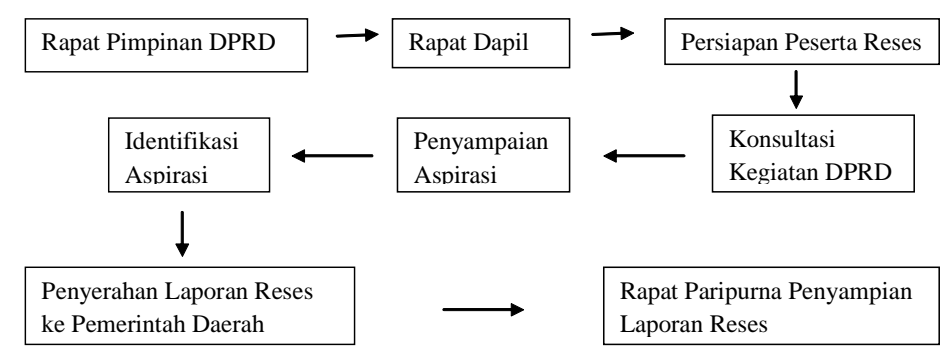

\section{GAMBAR 1 PROSES KEGIATAN RESES DPRD KABUPATEN OKU SELATAN}

Dari gambar diatas dapat dilihat bahwa, proses pertamapersiapan kegiatan reses ialah rapat Pimpinan DPRD. Rapat Pimpinan DPRD diikuti oleh Ketua DPRD, Wakil Ketua DPRD, Kordinator Daerah Pemilihan dan Sekretaris DPRD.Rapat Pimpinan DPRD bertujuan 
untuk menentukan jadwal pelaksanaan kegitanan reses. Proses kedua yakni, rapat Dapil yang diikuti oleh seluruh anggota DPRD yang berasal dari Dapil yang sama. Rapat Dapil dimaksutkan untuk membahas waktu pelaksanaan kegiatan reses. Proses ketiga yakni, persiapan peserta. Persiapan pesesrta berujuan untuk mempersiapkan aspirasi yang akan disampaikan oleh peserta reses pada saat reses.

Dari tabel diatas juga dapat dilihat bahwa, proses pertama pelaksanaan kegiatan reses ialah konsultasi kegiatan DPRD. Konsultasi kegiatan reses DPRD dimaksudkan untuk memberitahu dan meminta saran, kritikan dari peserta reses tentang kegitan DPRD sebeluum dan sesudah kegiatan reses.Proses kedua yakni penyampaian aspirasi oleh peserta reses. Peserta reses yang menghadiri kegiatan reses diberikan kesempatan untuk menyampaikan aspirasi.Proses ketiga yakni, identifikasi aspirasi. Aspirasi yang disampaikan oleh peserta reses tidak secara keseluruhan akan dimasukan ke dalam laporan kegiatan reses. Aspirasi yang disampaikan oleh peserta reses akan diidentifikasi bersama-sama antara DPRD dan peserta reses. Identifikasi aspirasi dimaksutkan agar aspirasi yang dimasukkan kedalam laporan reses memang benarbenar merupakan kebutuhan masyarakat. Proses keempat yakni rapat paripurna penyampaian laporan reses. Hasil identifikasi aspirasi dimasukkan kedalam laporan kegiatan reses DPRD dan disampikan saat rapat paripurna DPRD.Laporan kegiatan reses yang telah disampaikan pada rapat paripurna diserahkan kepada Pemerintah Daerah agar dapat diimplementasikan.

\section{ARTIKULASI ASPIRASI HASIL RESES DALAM PEMBAHASAN KUA DAN PPAS}

Artikulasi aspirasi masyarakat merupakan kegiatan yang dilakukan oleh setiap anggota DPRD untuk membuat, merumuskan dan menyampaikan aspirasi dalam pembahasan KUA dan PPAS. 
Dengan adanya artikulasi, aspirasi masyarakat dapat masuk dalam program-program yang akan dilaksanakan oleh Pemda ditahun yang akan datang. Dalam pembahasan KUA dan PPAS setiap Fraksi mempunyai peran yang penting agar aspirasi yang didapat melalui kegiatan reses dapat masuk dalam KUA dan PPAS.

Rancangan KUA dan PPAS merupakan muatan dari programprogram yang akan dilaksanakan oleh Pemda. Rancangan KUA dan PPAS disampaikan oleh Pemda kepada DPRD untuk dibahas bersama-sama antara DPRD dan Pemda dalam rapat paripurna. Dalam rapat paripurna pembahasan rancangan KUA dan PPAS, Pemda menyampaikan rancangan KUA dan PPAS terlebih dahulu, sebelum DPRD menyampaikan pandangan umum tentang rancangan KUA dan PPAS.Pandangan umum DPRD dalam menganggapi rancangan KUA dan PPAS yang diajukan oleh Pemda disampaikan oleh setiap Fraksi yang ada di DPRD Kabupaten OKU Selatan. Sebelum setiap Fraksi menyampaiakan pandangan umum tentang rancangan KUA dan PPAS, setiap Fraksi mengadakan rapat Fraksi untuk mempersiapakan pandangan umum yang akan disampaikan.

a. Fraksi Golkar

Acuan Fraksi Golkar dalam membahas rancangan KUA dan PPAS ialah aspirasi masyarakat, terutama aspirasi yang didapat dari kegiatan reses. Fraksi Golkar Dalam menyusun pandangan umum fraksi dilakukan dengan cara meminta pendapat setiap anggota fraksi. Pendapat setiap anggota fraksi terhadap rancangan KUA dan PPAS akan disusun bersama-sama dan dijadikan pandangan umum fraksi dalam menanggapi rancangan KUA dan PPAS. Fraksi Golkar juga menjadikan pandangan umum fraksi, sebagai pedoman bagi setiap anggota fraksi dalam mengikuti rapat komisi dalam membahas rancangan KUA dan PPAS.

b. Fraksi Demokrat 
Hasil identifikasi aspirasi yang didapat melalui kegiatan reses merupakan bahan utama yang digunakan oleh Fraksi Demokrat dalam meneliti dan membahas rancangan KUA dan PPAS. Berdasarkan aspirasi yang didapat dari reses I, II dan III Fraksi Demokrat memilah-milah terlebih dahulu aspirasi yang merupakan kebutuhan mendesak yang harus segera direalisasikan. Dalam mengartikulasikan aspirasi, hal yang menjadi pertimbangan yang digunakan oleh Fraksi Demokrat ialah, aspirasi yang merupakan kebutuhan mendesak danharus segera direalisasikan, merupakan hal yang sangan dibutuhkan oleh masyarakat dan diperkirakan dapat terrealisasi.

Proses pengartikulasian aspirasi dilakukan dengan memberikan kesempatan kepada setiap anggota fraksi untuk menyampaikan aspirasi yang harus segera direalisasikan disetiap Dapil. Pandangan umum yang disampaikan saat rapat fraksi, dijadikan acuan bagi setiap Anggota Fraksi Demokrat dalam mengikuti rapat komisi membahas dan meneliti rancangan KUA dan PPAS.

\section{c. Fraksi Bulan Bintang}

Fraksi Bulan Bintang, dalam menyusun pandangan umum fraksi yang menjadi acuan utama ialah Hasil identifikasi aspirasi yang didapat saat reses dan aspirasi yang didapat oleh anggota DPRD secara langsung dari masyarakat. Proses artikulasi dilakukan dengan cara aspirasi masyarakat dipilah-pilah terlebih dahulu berdasarkan mendesak atau tidak, prioritas atau tidak prioritas. Rapat Fraksi Bulan Bintang diadakan dengan cara mengkaji bersama-sama tentang rancangan KUA dan PPAS yang diajukan oleh Pemda dan meminta pendapat kepada seluruh anggota fraksi tentang rancangan KUA dan PPAS. Anggota fraksi yang berasal dari Dapil yang berbedabeda memberikan masukan yang akan disampaikan dalam pandangan umum fraksi yang disesuaikan dengan Dapil setiap anggota fraksi 
d. Fraksi Kebangkitan dan Keadilan Sejahtera

Artikulasi aspirasi dilakukan dengan cara anggota fraksi diminta untuk menyampaikan pandanganya tentang rancangan KUA dan PPAS dan menyampaikan hal-hal yang diperlukan didaerah pemilihanya masing-masing sesuai dengan aspirasi masyarakat. andangan umum fraksi tentang rancangan KUA dan PPAS disampaikan dalam rapat paripurna.Selain dsampaiakan dalam rapat paripurna pandangan umum fraksi juga diperjuangkan oleh anggota fraksi dalam rapat komisi dengan mitra kerja.

e. Fraksi Demokrasi Indonesia Perjuangan.

Acuan Fraksi PDI Perjuangan dalam menyusun pandangan umum fraksi ialah dipilih aspirasi yang benar-benar merupakan prioritas dan disesuaikan dengan kebutuhan masyarakat.Untuk menentukan aspirasi yang merupakan prioritas dan sesuai dengan kebutuhan masyarakat berdasarkan pendapat Anggota Fraksi yang lebih mengetahui keadaan daerah pemilihannya.Sehingga rapat fraksi yang diadakan oleh Fraksi PDI Perjuangan menghasilkan pandangan umum yang benar-benar prioritas.Pandangan umum fraksi dibagi kesetiap anggota fraksi yang disesuaikan dengan komisi dan mitra kerja. Sehingga anggota fraksi dalam mengikuti rapat komisi telah memahami apa yang harus diperjuangkan.

\section{f. Fraksi Hati Nurani Rakyat}

Dalam pembahasan pandangan umum, hal yang menjadi acuan Fraksi Hanura ialah aspirasi masyarakat didapat dari hasil kegiatan reses dan aspirasi yang disampaikan masyarakat kepada anggota DPRD secara langsung.Dalam rapat fraksi, setiap anggota fraksi diminta untuk menyampaikan tanggapan tentang rancangan KUA dan PPAS yang disampaikan oleh Pemerintah Deerah, dan hal-hal yang menjadi kebutuhan masyarakat di daerah pemilihanya berdasarkan aspirasi masyarakat didaerah pemilihanya.Tanggapan 
dan kebutuhan masyarakat ditampung menjadi pandangan umum fraksi.Pandangan umum fraksi dijadikan acuan bagi setiap anggota fraksi dalam mengikuti rapat komisi.Pandangan umum fraksi diberikan kepada anggota fraksi sesuai dengan komisi dan mitra kerja komisi yang berkaitan, sehingga anggota fraksi dapat memperjuangkan pandangan umum pada saat rapat dengan mitra kerja.

g. Fraksi Persatuan Pembangunan

Dalam rapat Fraksi PPP yang dijadikan acuan dalam membahas rancangan KUA dan PPAS ialah aspirasi masyarakat yang didapat saat reses. Berdasarkan aspirasi masyarakat setiap anggota fraksi diberikan kesempatan untuk menyampaikan aspirasi yang menjadi kebutuhan mendesak dan harus segera direalisasikan didaerah pemilihanya masing-masing..Agar pandangan umum fraksi dapat terrealisasi Fraksi PPP menjadikan pandangan umum fraksi acuan bagi setiap anggota fraksi dalam mengikuti rapat komisi dalam membahas rancangan KUA dan PPAS.

Strategi Fraksi Dalam Mengarahkan Aspirasi Hasil Reses Dalam Pembahasan KUA dan PPAS

Membahas dan meneliti Rancangan KUA dan PPAS merupakan kegiatan politik yang menyebabkan tarik menarik kepentingan antara sesama Anggota DPRD maupun dengan Pemda.Agar lembaga perwakilan dapat mengarahkan aspirasi masyarakat yang didapat melalui kegiatan reses kedalam program-program Pemda yang tertuang dalam APBD diperlukan strategi. Untuk melihat bagaimana strategi setiap fraksi yang ada di DPRD Kabupaten OKU Selatan dalam memperjuangkan dan mengarahkan aspirasi masyarakat dalam pembahasan KUA dan PPAS dapat dilihat dari tabel 2.

Dari tebel diatas dapat dilihat bahwa dalam mengarahkan aspirasi masyarakat yang didapat melalui kegiatan reses terdapat empat cara yang dilakukan oleh fraksi yang ada di DPRD OKU Selatan. Keempat cara tersebut ialah, melakukan lobi anggaran dengan 
Pemda, melakukan lobi anggaran dengan fraksi lain, mentargetkan setiap anggota fraksi minimal bisa mengarahkan satu aspirasi dan penyesuaian dengan anggaran.

Pertama lobi anggaran dengan Pemda.kegiatan lobi-lobi dengan Pemda dilakukan oleh setiap fraksi yang ada di DPRD Kabupaten OKU Selatan kecuali, Fraksi KKS. Lobi-lobi dengan Pemda diperlukan agar artikulasi aspirasi hasil reses dapat masuk dalam program Pemda. Pemda sebagai pemegang dan pelaksana anggaran memiliki peran yang penting dalam menentukan KUA dan PPAS serta memiliki posisi yang sama dengan DPRD dalam menentukan kebijakan anggaran

TABEL 2 STRATEGI FRAKSI DALAM PENGARAHAN ASPIRASI MASYARAKAT DALAM PEMBAHASANRANCANGAN KUA DAN PPAS

\begin{tabular}{|c|c|c|}
\hline Fraksi & & $\begin{array}{l}\text { Strategi Fraksi Dalam Pengarahan } \\
\text { Aspirasi Masyarakat Dalam Pembahasan } \\
\text { Rancangan KUA dan PPAS }\end{array}$ \\
\hline Fraksi & 1) & Lobi anggaran dengan Bupati \\
\hline Golkar & 2) & Lobi anggaran dengan fraksi lain \\
\hline Fraksi PDI & 1) & Mentargetkan setiap anggota fraksi bisa mengarahkan \\
\hline Perjuangan & & satu aspirasi \\
\hline & 2) & Melakukan lobi anggaran dengan Pemerintah Daerah \\
\hline Fraksi & 1) & Mendesak Pemda melalui lobi anggaran \\
\hline Demokrat & 2) & Penyesuain dengan anggaran \\
\hline Fraksi PBB & 1) & Melakukan lobi anggaran dengan fraksi lain \\
\hline & 2) & Secara pribadi melakukan lobi anggaran dengan Bupati \\
\hline Fraksi KKS & 1) & Melakukan lobi anggaran dengan fraksi lain \\
\hline Fraksi & 1) & Mendesak dinas-dinas terkait \\
\hline Hanura & 2) & Melakukan lobi anggaran dengan fraksi lain \\
\hline Fraksi PPP & 1) & Lobi anggaran dengan fraksi lain \\
\hline & 2) & Lobi anggaran dengan dinas terkait. \\
\hline
\end{tabular}

Sumber: Hasil wawancara dengan Ketua Fraksi DPRD Kabupaten OKU Selatan

Cara yang kedua yakni dengan lobi anggaran dengan fraksi lain yang ada di DPRD. Kegiatan lobi-lobi dengan fraksi lain dilakukan oleh Fraksi Golkar, PBB, Hanura, PPP dan Fraksi KKS. Lobi-lobi dengan Fraksi lain diperlukan mengingat Anggota DPRD terdiri 
dari banyak orang dan berasal dari fraksi yang berbeda-beda. Selain itu dalam hal pengambil keputusan di DPRD biasanya dilakukan dengan cara votting sangat jarang dilakukan dengan musyawarah mufakat. Hal lain yang membuat perlunya kegiatan dalam melobi fraksi lain dikarenakan setiap fraksi mempunyai agenda masingmasing.

Strategi yang ketiga yakni mentargetkan setiap anggota fraksi bisa mengarahkan satu aspirasi.Strategi ini dilakukan oleh Fraksi PDI Perjuangan. Target mengarahkan minimal satu aspirasi dalam rapat komisi merupakan cara agar setiap anggota fraksi berusaha semaksimal mungkin dalam memperjuangkan aspirasi masyarakat. Dengan adanya target juga membuat agenda Fraksi PDI Perjuangan dalam rapat paripurna dapat tercapai

Strategi yang keempat dengan cara penyesuaian dengan anggaran. Penyesuaian dengan anggaran dilakukan oleh Fraksi Demokrat.Melihat kondisi anggaran daerah yang masih sangat minim maka dalam pembahasan KUA dan PPAS Fraksi Demokrat dalam menentukan anggaran aspirasi yang diusulkan diambilkan dari anggaran yang dianggap tidak sesuai.Dengan ditemukanya anggaran yang tidak sesuai maka anggaran dari program tersebut diarahkan pada aspirasi yang diusulkan oleh Fraksi Demokrat.

\section{HASIL PENGARAHAN ASPIRASI DALAM PEMBAHASAN KUA DAN PPAS}

Untuk melihat perbandingan jumlah aspirasi hasil identifikasi kegiatan reses, yang termuat dalam Rancangan KUA dan PPAS, aspirasi tambahan dan keseluruhan aspirasi yang termuat dalam KUA dan PPAS di Dapil I, II dan III dapat dilihat dari tabel 3.

Berdasarkan tabel diatas dapat dilihat bahwa, di Dapil I, dari 66 aspirasi hasil reses terdapat 19 aspirasi yang termuat dalam rancangan KUA dan PPAS yang diusulkan oleh Pemerintah Daerah. Hasil kesepakatan antara Pemerintah Daerah dan DPRD terdapat 
penambahan 13 aspirasi yang termuat dalam KUA dan PPAS.Secara keseluruhan di Dapil I terdapat 32 aspirasi hasil hasil reses yang termuat dalam KUA dan PPAS hasil kesepakatan antara Pemerintah Daerah dengan DPRD.

TABEL 3 ASPIRASI HASIL RESES I, II DAN III YANG TERMUAT DALAM RANCANGAN KUA DAN PPAS DAN KUA DAN PPAS

\begin{tabular}{lllll}
\hline Dapil & $\begin{array}{l}\text { Aspirasi Hasil } \\
\text { Reses }\end{array}$ & $\begin{array}{l}\text { Rancangan KUA dan } \\
\text { PPAS }\end{array}$ & $\begin{array}{l}\text { Aspirasi } \\
\text { Tambahan }\end{array}$ & KUA dan PPAS \\
\hline Dapil I & 66 & 19 & 13 & 32 \\
\hline Dapil II & 99 & 8 & 18 & 25 \\
\hline Dapil III & 77 & 9 & 10 & 19 \\
\hline Jumlah & 242 & 36 & 41 & 76 \\
\hline
\end{tabular}

Sumber: Risalah Sidang DPRD dalam Rangka Membahas dan Meneliti Rancangan KUA dan PPAS Tahun 2014 dan KUA dan PPAS Kabupaten OKU Selatan Tahun 2014 Data diolah

Berdasarkan tabel diatas, di Dapil II dari99 aspirasi hasil reses terdapat 8 aspirasi yang termuat dalam rancangan KUA dan PPAS. Hasil kesepakatan antara Pemerintah Daerah dan DPRD terdapat penambahan 18 aspirasi yang termuat dalam KUA dan PPAS. Hasil kesepakatan DPRD dan Pemerintah Daerah juga terdapat 1 aspirai yang termuat dalam rancangan KUA dan PPAS dan tidak termuat dalam KUA dan PPAS .Secara keseluruhan di Dapil II terdapat 25 aspirasi hasil reses yang termuat dalam KUA dan PPAS hasil kesepakatan antara Pemerintah Daerah dengan DPRD.

Berdasarkan tabel diatas juga dapat dilihat bahwa, di Dapil III, dari 77 aspirasi hasil reses terdapat 9 aspirasi yang termuat dalam rancangan KUA dan PPAS yang diusulkan oleh Pemerintah Daerah. Hasil kesepakatan antara Pemerintah Daerah dan DPRD terdapat penambahan 10 aspirasi yang termuat dalam KUA dan PPAS.Secara keseluruhan di Dapil III terdapat 19 aspirasi hasil hasil reses yang termuat dalam KUA dan PPAS hasil kesepakatan antara Pemerintah Daerah dengan DPRD.

Secara keseluruhan, aspirasi hasi reses DPRD Kabupaten OKU Selatan tahun 2013 sebanyak 242 aspirasi.Aspirasi hasil reses yang 
termuat dalam rancangan KUA dan PPAS sebanyak 36 aspirasi.Hasil kesepakatan anatara Pemerintah Daerah dan DPRD terdapat 41 penambahan aspirasi yang termuat dalam KUA dan PPAS.secara keseluruhan dari 242 aspirasi yang didapat melalui kegiatan reses terdapat 76 aspirasi yang termuat dalam KUA dan PPAS hasil kesepakatan antara Pemerintah Daerah dan DPRD.

\section{KESIMPULAN DAN SARAN}

Berdasarkan hasil penelitian, dan pembahasan tentangAnalisis Hasil Reses Dewan Perwakilan Rakyat Daerah dalam Penyusunan dan Penetapan Anggaran Pendapatan dan Belanja Daerah Kabupaten Ogan Komering Ulu Selatan tahun anggaran 2014, maka dapat disimpulkan beberapa hal sebagai berikut:

1. Proses pelaksanaan kegiatan reses di Kabupaten OKU Selatan dimulai dengan persiapan kegiatan reses. Persiapan kegiatan reses dilakukan oleh DPRD dan peserta reses. Persiapan DPRD dilakukan dengan rapat Pimpinan DPRD untuk menentukan jadwal kegiatan reses. Hasil rapat Pimpinan DPRD dibahas dalam rapat Anggota DPRD yang berasal dari daerah pemilihan yang sama untuk menetukan waktu, tempat dan pendokumentasian kegiatan reses. Kegiatan reses yang dilakukan oleh DPRD dilaksanakan dengan mengunjungi setiap kecamatan yang ada di Kabupaten OKU Selatan dan dilaksanakan selama tiga jam. Persiapan peserta reses dilakukan untuk menentukan aspirasi yang akan disampaikan saat reses. Aspirasi yang akan disampaikan saat reses berasal dari Hasil Musrembangdes, aspirasi yang disampaikan saat reses sebelumnya dan belum terrealisasi dan rapat Pemerintahan Desa.

2. Pelaksanaan kegiatan reses pertama diikuti oleh 1237 peserta, reses kedua sebanyak 884 peserta dan reses ketiga sebanyak 1080 peserta. Hal pertama yang menjadi pembahasan dalam pelaksanaan kegiatan reses ialah konsultasi kegiatan DPRD 
sebelum dan sesudah reses. hal kedua yakni penyampaian aspirasi oleh peserta reses. aspirasi yang disampaikan oleh peserta reses akan diidentifikasi bersama antara peserta reses dan DPRD. Identifikasi aspirasi akan dijadikan laporan kegiatan reses dan akan disampaikan kepada Pemerintah Daerah.

3. Hasil identifikasi aspirasi di artikulasikan oleh DPRD pada saat membahas dan meneliti Rancangan KUA dan PPAS bersama Pemerintah Daerah. Artikulasi aspirasi dibahas dalam rapat fraksi pada saat membahas pandangan umum fraksi. Pandangan umum fraksi disusun dengan cara meminta pendapat Anggota Fraksi tentang Rancangan KUA dan PPAS. Pandangan umum fraksi dijadikan acuan Anggota Fraksi dalam rapat komisi dan rapat badan anggaran.

4. Strategi fraksi dalam mengarahkan dan memperjuangkan aspirasi masyarakat dilakukan dengan empat cara. Keempat strategi tersubut ialah melakukan lobi anggaran dengan Pemerintah Daerah, melakukan lobi anggaran dengan fraksi lain, mentargetkan setiap anggota fraksi minimal bisa mengarahkan satu aspirasi dan penyesuaian dengan anggaran daerah.

5. Aspirasi yang didapat melalui kegiatan reses dapat diartikulasikan dengan baik oleh DPRD Kabupaten OKU Selatan. Hal ini didapat dilihat dari banyaknya aspirasi yang didapat melalui kegiatan reses yang termuat dalam KUA dan PPAS. Secara keseluruhanhasil identifikasi aspirasi di Dapil I, II dan III terdapat 36 aspirasi yang termuat dalam Rancangan KUA dan PPAS. Berdasarkan kesepakatan antara Pemda dan DPRD terdapat penambahan 41 aspirasi yang termuat dalam KUA dan PPAS dengan tambahan. Secara keseluruhan aspirasi hasil identifikasi kegiatan reses DPRD Kabupaten OKU Selatan terdapat 76 aspirasi yang termuat dalam KUA dan PPAS.

Berdasarkan hasil kesimpulan tersebut di atas, maka peneliti 
menyarankan beberapa hal sebagai berikut:

1. Meningkatkan sosialisasi jadwal kegiatan reses kepada masyarakat agar peserta reses yang menghadiri kegiatan reses tidak hanya peserta yang mendapatkan undangan secara formal.

2. Mengikutsertakan unsur Pemerintah Daerah dalam mengikuti kegiatan reses

3. Menekan Pemerintah Daerah agar laporan kegiatan reses dijadikan acuan dalam penyusunan Rancangan KUA dan PPAS.

4. Menekan Pemerintah Daerah agar meningkatkan efektifitas sektor-sektor potensial untuk meningkatkan pendapatan asli daerah agar dapat mewujudkan aspirasi masyarakat.

\section{DAFTAR PUSTAKA}

Abe, Alexander. 2002. Perencanaan Daerah Partisipatif. Solo. PondokEdukasi

Anthony, Robert N, dan Vijay Govindarajan. 2006. SistemPengendalianManajemen. terjemanan FX. KurniawanTjakrawala. Jakarta. SalembaEmpat.

Conyers, Diana. 1994. PerencanaanSosial di DuniaKetiga. Yogyakarta.Gajah Mada University Press.

Efriza. 2014. StudiParlemen, Sejarah, KonsepdanLanskapPolitik Indonesia. Malang. Setara Press.

Huntington, P, Samuel dan Nelson, M, Joan. 1997. PartisipasiPolitik di Negara Berkembang. Jakarta. SangkalaPulsara. Karianga, Hendra. 2011. PartisispasiMasyarakatDalamPengelolaanKeuangan Daerah. Bandung. Alumni.

Mardiasmo. 2009. AkuntansiSektorPublik. Cetakankeempat.Yogyakarat.Andi

Marijan, Kacung. 2011.SistemPolitik Indonesia KonsolidasiDemokrasi Pasca OrdeBaru. Jakarta. KencanaPrenada Media Group.

Moeleong, I Lexy. 2014. MetodelogiPenelitianKualitatif. Bandung. RemajaRosdakarya.

Rubin, IreneS. 2006. The Politics of Public Budgeting: Getting and Spending Borrowing and Balencing. Chantam.Chantam House.

Sugiyono. 2014. MemahamiPenelitianKualitatif. Bandung. Alfabeta

Syaukani HR, GaffarAfandanRasyidRyaas. 2009. Otonomi Daerah Dalam Negara Kesatuan. Yogyakarta.PustakaPelajar. Tarigan, Robinson. 2012. Perencanaan Pembangunan Wilayah. Jakarta. BumiAksara.

UsmanSunyoto. 2004. JalanTerjalPerubahanSosial.Yogyakarta.CIReD.

Waidl, Abdul. 2008. Mendahulukan Si Miskin. Yogyakarta.LKIS.

Wildavsky, Aaron. 1974. The Pollitics of the Budgetary Process. Boston. Little Brown.

\section{JURNAL}

Sopanah, Ana. 2012. Ceremonial Budgeting: Public Participation in Development Planning at an Indonesian Local Government Authority." Journal of Applied Management Accounting Research Volume 10.Nomor 2.

Takeshi, Ito. 2006. The dynamics of local governance reform in decentralizing Indonesia: participatory planning and village empowerment in Bandung, West Java. Asian and African Area Studies, Volume 5.Nomor2. 


\section{PERATURAN}

Undang-UndangNomor 27 Tahun 2009 tentangMajelisPermusyawaratan Rakyat, DewanPerwakilan Rakyat, DewanPerwakilan Daerah danDewanPerwakilan Rakyat Daerah.

BPS OKU Selatan.OKU Selatan dalamangka 2014.

PrioritasdanPlafonAnggaranSementaraAnggaranPendapatandanBelanja Daerah (PPAS APBD) KabupatenOganKomeringUlu Selatan TahunAnggaran 2014

RisalahSidangParipurnaDewanPerwakilan Rakyat Daerah KabupatenOganKomeringUlu Selatan DalamRangkaMembahasdanMenelitiRancangan KUA dan PPAS APBD KabupatenOganKomeringUlu Selatan TahunAnggaran 2014

LaporanHasil Reses Ke 1, II dan III Tahun 2013 AnggotaDewanPerwakilan Rakyat Daerah KabupatenOganKomeringUlu Selatan

UU No 33 Tahun 2004 tentang Perimbangan Keuangan antara Pemerintah Pusat dan Pemerintah Daerah Internet

AksesMasukkeDanauRanauDipenuhiBelukar. 2013. Diperolehdarihttp://palembang. tribunnews.com/2013/06/18/aksesmasuk-ke-danau-ranau-dipenuhi-belukar. Diakses 21 Februari 2015 